\title{
Dividend Payout Effects on Firm Performance in Nigerian Oil and Gas Sector
}

\author{
Mahmood Omeiza Adeiza1, Abubakar Sabo², Moshood Abdulrasheed Abiola ${ }^{1}$ \\ ${ }^{1}$ Department of Accounting, Faculty of Management Sciences, Usmanu Danfodiyo University, Sokoto, Nigeria \\ ${ }^{2}$ Department of Business Administration, Faculty of Management Sciences, Usmanu Danfodiyo University, \\ Sokoto, Nigeria \\ Email:mudillicious@gmail.com,mahmood.adeiza@udusok.edu.ng, abyabo4@gmail.com,moshooda86@gmail.com
}

How to cite this paper: Adeiza, M. O. Sabo, A., \& Abiola, M. A. (2020). Dividend Payout Effects on Firm Performance in Nigerian Oil and Gas Sector. Open Journal of Social Sciences, 8, 370-385. https://doi.org/10.4236/jss.2020.87030

Received: June 5, 2020

Accepted: July 28, 2020

Published: July 31, 2020

\section{Copyright (c) 2020 by author(s) and} Scientific Research Publishing Inc. This work is licensed under the Creative Commons Attribution International License (CC BY 4.0).

http://creativecommons.org/licenses/by/4.0/

(c) (i) Open Access

\begin{abstract}
To address the need for more answers regarding effects of dividend payout on firm performance of quoted oil and gas companies in Nigeria, this study set out to ascertain the effect of Dividend Payout Ratio (DPR) on Net Profit Margin of quoted oil and gas companies, to determine the effect of Dividend Payout Ratio (DPR) on the Return of Asset (ROA) of quoted oil and gas companies as well as to identify the effect of Dividend Payout Ratio (DPR) on the Return on Equity (ROE) of quoted oil and gas companies. Accordingly, Ratio Analyses (Dividend Payout Ratio and Profitability Ratio) were adopted as analytical tools for deciphering the relationship between variables in the financial statement of two oil and gas firms (Total Plc and Mobil Plc) to identify fundamental trends and relationships that often cannot be noted by individual inspection of components of the ratio. The research made use of secondary data obtained from financial reports of the companies. The study found that Dividend Payout Ratio had a negative and insignificant effect on firm performance of Mobil Plc and Total Plc in 2017 and 2018, while the results showed significant effect in 2015 and 2016 for Total Plc, and significant effect for Mobil Plc in 2015 but insignificant effect in 2016. Inclusively, the study concluded that payment of dividend and the payout ratio conveys to shareholders that the companies are profitable and financially strong and recommended that managers: devote time to as well as design dividend policies that will enhance financial performance and shareholders' value; and reduce company total debts to increase financial performance of firms and shareholder value.
\end{abstract}

\section{Keywords}

Dividend Payout Ratio, Profitability Ratio, Firm Performance, ROE, ROA, Net Profit Margin 


\section{Introduction}

Dividend announcements are perceived as suppliers of the missing bits of information regarding a corporate firm's market estimation of its current earnings but while investors may have greater confidence that reported earnings reflect economic profits when announcements are accompanied by ample dividends (Miller \& Rock, 1985). Dividend payout has influenced the performance evaluation of various companies. Thus, performance evaluation of various companies can be viewed from different perspectives and there are also different indicators for measuring firm's performance. There are many definitions of performance given by different scholars. But according to Rahel \& Serkalem (2010), they viewed performance in terms of profitability; they defined performance as, profitability which is the financial goal of every firm, used to expand the firm and to serve as a cushion for future slow periods. They posited that profitability also helps a firm to ensure its solvency for owners to invest in the future and firms can go out of business, if it incurs loses and become insolvent and profit is generally attained only when company operates effectively and efficiently.

An overview of dividend payout pattern shows that profitable mature firms pay higher dividend than younger rapidly growing ones. For instance, the British firms have the highest payouts in the industrialized world. North America companies have higher payouts in the industrialized world. North America companies have higher payouts than the Western European or Japanese companies. This is simply because the former use capital market for financing while the latter use intermediated financing. In contrast, France with strong socialist traditions and Italy with long state intervention tend to discourage dividend payment (Amadasu, 2011). Since the discovery of crude oil in Nigeria, particularly how frequently petroleum is used, by volume, for producing fuel oil and gasoline (petrol), both importantly "primary energy" sources; $84 \%$ by volume of the hydrocarbons present in petroleum is converted into energy-rich fuels (petroleumbased fuels) including; gasoline, diesel, jet, heating, and other fuel oils, and liquefied natural gas; due to its high energy density, easy transportability and relative abundance, it has become the world's most important source of energy since the mid-1950s.

This crude oil has contributed largely to the economy and revenue of both government and other stakeholders involved. According to Odularu (2008) 80\% of Nigeria's energy revenues flow to the government and about $4 \%$ go to investors. It is worthy to note that this revenue figures run into billions of dollars. Over the years, the petroleum industry has attracted stakeholders from foreign and local explorers whom have benefited greatly as a result of increase in its price. Oil and gas firms or companies in the Nigerian Stock Exchange (NSE) are believed to be financially viable and as a result, shareholders require favourable dividend policies which will maximize their wealth as a result of increase firm's performance. Managers are saddled with the responsibility of making optimum investment decisions on behalf of the firm and ensuring the maximization of 
shareholders' wealth. This can be achieved when firms generate sufficient profits and strategically decide the amount to be reinvested into the firm or distributed to shareholders. The distributed funds to shareholders are known as dividends.

Moreover, companies in developing countries like, Nigeria have low dividend payout if they perhaps pay at all. Therefore, the empirical studies which have mainly focused on developed economics show that there is a relationship between the dividend payout and financial performance of companies in Nigeria. Current dividend payment reduces investors to discount the firm earnings at lower rate of return while dividend reduction increases investors' uncertainty, raising the required rate of return. Therefore, dividend payout has effect on the financial performance of oil and gas companies. Consequently, this study's scope is narrowed down to two quoted oil and gas companies in Nigeria. To the best of the knowledge of the researchers, no model or theory has focused on dividend policy as to how it affects share price. However, further research has to be done on the effect of dividend payout on performance evaluation of quoted oil and gas companies in Nigeria using more recent data of Nigeria Stock Exchange (NSE).

The researchers adopted four (4) variables for the analysis since there were many conflicting findings on the subject matter over the years which necessitated the need to carry out a research on the subject matter using new data of Nigeria Stock Exchange (NSE). The variables employed are as follows: Dividend Payout Ratio (DPR); Net Profit Margin; Return on Assets (ROA), Return on Equity (ROE). Hence, it is simply an attempt to fill the gap by empirically investigating the effect of dividend payout on performance evaluation of quoted oil and gas companies on Nigeria Stock Exchange (NSE). The work aimed to actualize the following objectives: To ascertain the effect of Dividend Payout Ratio (DPR) on Net Profit Margin of quoted oil and gas companies on Nigeria Stock Exchange. To determine the effect of Dividend Payout Ratio (DPR) on the Return of Asset (ROA) of quoted oil and gas companies on Nigeria Stock Exchange. To identify the effect of Dividend Payout Ratio (DPR) on the Return of Equity (ROE) of quoted oil and gas companies on Nigeria Stock Exchange.

The problem of this study is that answers regarding the effects of dividend payout on firm performance in the Nigerian oil and gas sector have not been sufficient in theoretical and empirical literature. Establishing the effect of dividend payout ratio on the financial performance of oil and gas companies in $\mathrm{Ni}$ geria has become paramount thus, the following research questions are posed in order to achieve the objectives of the study: To what extent does Dividend Payout Ratio (DPR) affect the Net Profit Margin of quoted oil and gas companies on Nigeria Stock Exchange? Does Dividend Payout Ratio (DPR) have any effect on the Return of Asset (ROA) of quoted oil and gas companies on Nigeria Stock Exchange? How persuaded are you that Dividend Payout Ratio (DPR) have any effect on Return on Equity (ROE) of quoted oil and gas companies on Nigeria Stock Exchange?

Ratio analysis was adopted in this research. Ratio analysis is an analytical tool 
use to establish relationship between variables in the financial statement of each firm in order to identify significant fundamental and structural relationships and trends as well as disclose relationships which reveal conditions and trends that often cannot be noted by individual inspection of components of the ratio. The research makes use of secondary data, the financial reports obtained from statistical bulletin of Mobil Plc and Total Plc from 2015 to 2018. The ratio analysis used in this research is Dividend payout ratio and Profitability ratio. Dividend payout ratio is used to analyse the two companies' dividend policy and profitability ratios are used to examine the financial performance so as to analyze how successful a firm is, in its operation. Although, ratios are not sole factors for decision making, but provide concrete evidences to decision regarding financial statement of a firm. Therefore, the dividend payout ratio and profitability ratios are adopted to determine the effect of dividend payout on the financial performance of Mobil Plc and Total Plc.

While dividend payout ratio shows what percentage of the company's distributable earnings is being paid to the ordinary shareholders in the form of dividend (thus, "dividend per share" divided by "earning per share"), Net Profit Margin indicates the Naira amount of the net profit the firm accrued from each Naira of net sales. So, Net Profit Margin equals Net profit divided by Sales. Also, Return on Assets (ROA) indicates management performance in using the company's total assets to generate return (that is, PBT divided by Total Assets) while Return on Equity (ROE) shows the efficiency of management to maximize the return to shareholders base on their investment in the business (hence, PBT divided by Equity). According to Deltacpe (2014), Ratios are generally not significant of themselves but assume significance when they are compared with: 1) previous ratios of the same firm, 2) some predetermined standards 3) ratios of other enterprises in the same industry, or 4) ratios of the industries within which the company operates. Therefore, for this study, the two sampled companies will be compared.

\section{Literature Review}

This literature review consists of three frameworks: conceptual, theoretical and empirical. Attempt was made to clarify some concepts, give theoretical reinforcement to the study as well as ascertain the gap from which a statement of the research problem has been derived.

\subsection{Conceptual Framework}

\subsubsection{Regular Dividend}

Regular and stable dividend are considered a desirable policy by management of most firms, shareholders also favors this policy and value stable dividend more than the fluctuating ones. All things been equal stable dividend can have positive impact on the market value of shares. Stability in dividend means the amount paid but regularly to shareholders. 


\subsubsection{Dividend Payout Policy}

The implication of dividend payout on companies is however complex. A high dividend payout policy means more current dividends and less retained earnings, which may consequently result in slower growth and perhaps lower market price per share. Low payout policy means less current dividends, more retained earnings and higher capital gains. Therefore, it is plausible that some investors will prefer high-payout companies while others may prefer low-payout companies. It is important to note that paying dividends involves outflows of cash; the cash accountable for the payment of dividend is affected by the companies' investment and financial decision.

A decision for inquired capital expenditure means that less cash would be available for the payment of dividend. Given firm's capital expenditure that do not have sufficient internal funds to pay dividends can raise funds by issuing per share. In this case, a dividend decision is not separable from the firms' decisions. The firm will have a given amount of firm fort paying dividend given its investment and financial decisions. A dividend decision involves a trade-off between the retained earnings and issues of new shares. A higher dividend payout attracts more investors and when there is a rush for the company's stock, the price of the stock will move up, this is known as regular effects. But, a lower dividend payout on the other hand will discourage many investors from investing and this intent can lead to reduction in the price of shares of that particular firm.

A dividend has been declared as the causes of change in financial performance evaluation of companies or firms. The issue of dividend payout is a very crucial matter in the current business environment and more especially on the performance evaluation of firms. Individuals invest in firms or companies mainly because they expect some returns from the later. A dividend is a payment by a corporation to its shareholders, usually as a distribution of profit. When a corporation earns a profit or surplus, the corporation is able to re-invest the profit in the business (retained earnings) and pay a proportion of the profit as a dividend to shareholders. Distribution to shareholders may be in cash (usually a deposit into a bank account) or, if the corporation has a dividend reinvestment plan, the amount can be paid by the issue of further shares or share repurchase.

When dividends are paid, shareholders typically must pay income taxes, and the corporation does not receive a corporate income tax deduction for the dividend payments. More so, dividend payout is the regulations and guidelines that a company uses to decide whether to make dividend payments to shareholders or not. Companies come into existence with an aim to maximize the wealth of their shareholders and the value of the company as a whole. The dividend payment decisions of firms are the primary element of any corporate policy which is basically the benefits of shareholders in return for investing their money in that particular organization.

A dividend policy is expected to lead higher share prices because of the greater confidence of investors about the future prospects of the company. Enhancing shareholders' wealth and profit making are among the major objectives of a firm 
(Pandey, 2003). The dividend payout ratio measures the percentage of net income that is distributed to shareholders in the form of dividends during the year. In other words, this ratio shows the portion of profits the company decides to keep funding operations and the portion of profits that is given to its shareholders. Investors are particularly interested in the dividend payout ratio because they want to know if companies are paying out a reasonable portion of net income to investors. For instance, most startup companies and tech companies rarely give dividends at all (Benartzi et al., 1997).

The dividend payout of firms is not only the source of cash flow to the shareholders but it also serves as informant to shareholders, regulatory agencies, potential investors and government about the information relating to firm's current and future performance. Hashemijoo et al. (2012) sees dividend policy as a company's policy which determines the amount of dividend payments and the amounts of retained earnings for reinvesting in new projects. The philosophy of dividend is that the investors would not want any dividend less than the expected except they have the conviction that the investment to which the retained earnings are committed would yield returns over and above what they could be opportune to elsewhere.

Dividend payout is the amount of cash that a company sends to its shareholders in the forms of dividends. The company can decide to send all the profits back to its shareholders or investors, or could keep a portion of it as retained earnings. Healthy dividends payouts thus indicate that companies are generating real earnings (Barron, 2002). A dividend is a distribution from a firm to its investors (Welch, 2009). Dividend payout ratio is the fraction of net income a firm pays to its stockholders in dividends. The part of the earnings not paid to investors is left for investment to provide for future earnings growth .Dividends are the distribution of a company's gains over a fixed period of time to shareholders (Brigham \& Houston, 2004).

\subsection{Theoretical Framework}

The concept of dividend has been defined by many authors and researches. Bierman (2001); Baker et al. (2002); Wansley (2003) have described it as an appropriation of profits to shareholders after deducting tax and fixed interest obligations on debt capital. Dividends are compensatory distribution to equity shareholders for both time and investment risks undertaken (Uwuigbe et al., 2012). Pandey (2010) defines dividend as a portion of a company's net earnings which the directors recommend to be distributed to shareholders in proportion to their shareholdings in the company. It is usually expressed as a percentage of nominal value of the company's ordinary share capital or as a fixed amount per share. Dividends are usually paid out of the current year's profit and sometimes out of general reserves. They are normally paid in cash and dividend payment is known as cash dividend. Dividend payment is a major component of stock return to shareholders (Zakaria et al., 2012). 
Jo \& Pan (2009) assert that dividend payment could provide a signal to the investors that the company is complying with good corporate governance practices. According to Van Horne (1971) dividend policy entails the division of earnings between shareholders and reinvestment in the firm. Retained earnings are a significant source of funds for financing corporate growth, while dividend constitutes the cash flows that accrue to shareholders. Dividend payout is the amount of cash that a company sends to its shareholders in the forms of dividends. The company can decide to send all the profits back to its shareholders or investors, or could keep a portion of it as retained earnings. Healthy dividends payouts thus indicate that companies are generating real earnings rather than cooking books (Barron, 2002).

According to William \& Scott (2009), dividend is referred to as a periodic cash payment that firms make to investors who holds the firms' preferred or common stock. In developed countries, the decision between paying dividend and retained earnings has been taking seriously by both investors and management, and has been the subject of considerable research by economists in the last four decades (Lintner, 1956; Brittain, 1964; Modigliani \& Miller, 1961; Black \& Scholes, 1974; Dhillon \& Johnson, 1994; Amihud \& Murgia, 1997; Chariton \& Vafeas, 1998; as cited in Adelegan, 2003).

According to Van Horne (1971) dividend policy entails the division of earnings between shareholders and reinvestment in the firm. Retained earnings are a significant source of funds for financing corporate growth, while dividend constitutes the cash flows that accrue to shareholders. There exist two divergent schools of thought with regard to these, the dividend policy and the retained earning policy. Dividend policy suggests a positive attitude, for it is a deliberate policy to maintain dividend at a certain level or increase it, with the ultimate aim of sustaining the price of the ordinary shares on the stock exchange. This is because capital markets are not perfect, and although shareholders are indifferent to the ratio between dividend and retained earnings due to market imperfections and uncertainty, they give a higher value to the current year dividend than the future dividend and capital gains. Thus the payment of dividend has a strong influence on the market price of the shares.

Management might maintain a dividend level even at the expense of liquidity or be forced into borrowing to do so. Within this approach, dividends are thought to be desirable from the shareholders' point of view, as increasing their current wealth and dividend level determines share price as well as indicates the prospect of profitability of the firm. The second school of thought which promotes the profit retention policy tends to suggest a more passive residual attitude towards dividend as dividend payout reduces the amount of earnings to be retained in the firm and affects the total amount of internal financing.

When dividends are treated as a financing decision, the net earnings of the firm may be viewed as a significant source of financing the growth of the firm. Dividends paid to shareholders represent a distribution of earnings that cannot 
be profitably reinvested by the firm. The approach to dividend is viewed merely as a residual decision. This theory is known as the residual theory of dividend and was first proposed by Miller and Modigliani in 1961. Investors prefer to have the firm retain and reinvest earnings rather than pay them out in dividend if the return on the investment earnings exceeds the rate of return the investors could themselves obtain on other comparative investment. Otherwise, the investors prefer dividend.

Based on the research questions, the following null hypotheses were formulated:

$\mathrm{H}_{1}$ : There is no significant effect of Dividend Payout Ratio (DPR) on Net Profit Margin of quoted oil and gas companies on Nigeria Stock Exchange.

$\mathrm{H}_{2}$ : Dividend Payout Ratio (DPR) has no significant effect on Return on Asset (ROA) of quoted oil and gas companies on Nigeria Stock Exchange.

$\mathbf{H}_{3}$ : Dividend Payout Ratio (DPR) has no significant effect on Return on Equity (ROE) of quoted oil and gas companies on Nigeria Stock Exchange.

\subsection{Empirical Framework}

Dividend policy remains a source of controversy despite years of theoretical and empirical research, including one aspect of dividend policy: the linkage between dividend policy and stock price (Nissim \& Ziv, 2001). Paying large dividends reduces risk and thus influence stock price (Gordon, 1963) and a proxy for the future earnings (Baskin, 1989). Dividends are relevant because they have informational value. Financial signaling theory posits that dividends maybe used to convey information. Information, rather than dividend itself, affects share prices (Brigham \& Gapenski, 1994). Corporations view the dividend decision as important because it determines what funds flow to investors and what funds are retained by the firm for reinvestment (Ambarish, John, \& Williams, 1987).

According to Miller \& Modigliani (1961), the dividend decision does not affect the firm's value and is therefore irrelevant. This was arrived at given perfect market conditions such as no taxes, no transaction costs, perfect competition and costless information. Other renowned finance scholars who agreed with Modigliani and Miller include: De Angelo et al. (1996), Lang \& Litzenberger (1989). There are other scholars who hold that dividends are relevant. They include Watts (1973), Lintner (1956), Miller (1987), Aharony \& Swary (1980), Asquith \& Mullins (1983), Pettit (1972), Benartzi, Michealy, \& Thaler (1997).

Rahim et al. (2010) detected a symptom of underinvestment when there was positive relationship between dividend policy and the firm's value. The increase in firm's value was contributed by the decreased in investment, increased dividend and stagnant debt ratio. They suggested that underinvestment happens because the management cautiously chooses only secured investments and distributes the excess cash to shareholders as dividends. While trying to advance the issue of dividend policy and firm performance, Zanjidar \& Seifi (2012) investigated the relationship between dividend and company performance. Conse- 
quently, two groups of performance indices based on economic trend and accounting trend were studied. Ninety-Three companies whose required information was available were chosen for a period of 6 years (2004-2009). The experimental results of the study showed that, there is a positive relationship between economic and accounting performance indices and dividend policy, and that accounting performance indicators have more explanatory power than economic performance indicators and concluded that dividend policy affects firms' performance.

Rashid \& Rahman (2008) found that there is positive but insignificant relationship between share price volatility and dividend yield for 104 non-financial firms listed in the Dhaka Stock exchange during the period of 1999-2006. Nazir et al. (2010) applied fixed effect and random effect models to test the role of corporate dividend policy in determining the volatility in the stock price for 73 firms listed in Karachi Stock Exchange (KSE-100) indexed. Contradict to Rashid \& Rahman (2008), the researcher found that the share price volatility is significantly influence dividend policy as measured by dividend payout ratio and dividend yield. The result of the empirical findings made by Zakaria et al., 2012 also suggests there is a significant positive relationship between the dividend payout ratio of a firm and share price volatility.

Musyoka (2015) studied the effect of dividend policy on the financial performance of firms listed on the Nairobi stock exchange. 20 companies were sampled for a period of 5 years (2010-2014). The study revealed that all the variables (independent) had significant relationship with dividend policy except for firm size and leverage, which revealed negative effect; this finding is in conformity with the outcome of Waswa et al. (2014). Gwaya \& Mwasa (2016) in their study sought to examine how dividend policies of selected public limited companies in Kenya affect financial performance during the period 2002-2011. They took a sample of 29 companies listed on Nairobi Stock exchange. The findings of their research established that dividend policy of firms has an effect on its subsequent financial performance.

Foong, Zakaria, \& Tan (2007) also stressed the fact that investments made by firms' influences the future earnings and future dividends potential. In their research on 50 listed firms operating in high profile industries in the Nigerian Stock Exchange, Uwuigbe et al. (2012) observed that firm performance has a significant impact on the dividend payout of listed firms in Nigeria. That is, an increase in the financial well-being of a firm tends to positively affect the dividend payout level of firms. However, Adefila et al. (2013) concludes that Nigerian firms do have a dividend policy that is dependent on earnings though the trend is not very consistent and proportionate. This is in agreement with the assertion made by Uwuigbe et al. (2012) that while several prior empirical studies from developed economies have shed light on the relationship between firm performance and dividend payout, the same is not true in developing economies like Nigeria. 
The summary of this empirical review suggests that more answers regarding the effects of dividend payout on firm performance in the Nigerian oil and gas sector are needed for establishing the effects of dividend payout ratio on the performance of quoted oil and gas companies in Nigeria.

\section{Research Methodology}

\subsection{Data Description and Sources}

Ratio analysis was adopted in this research. Ratio analysis is an analytical tool use to establish relationship between variables in the financial statement of a firm, it can identify significant fundamental and structural relationships and trends, and can disclose relationships which reveal conditions and trends that often cannot be noted by individual inspection of components of the ratio. The research makes use of secondary data, the financial reports obtained from statistical bulletin of Mobil Plc and Total Plc from 2015 to 2018.

\subsection{Ratio Analysis}

The ratio analysis used in this research is Dividend payout ratio and Profitability ratio. Dividend payout ratio is used to analysis the two companies' dividend policy, and profitability ratios are used to examine the financial performance so as to analyze how successful a firm is, in its operation. Although, ratios are not sole factors for decision making, but provide concrete evidences to decision regarding financial statement of a firm. Therefore, the dividend payout ratio and profitability ratios are adopted to determine the effect of dividend payout on the financial performance of Mobil Plc and Total Plc.

\subsubsection{Dividend Payout Ratio}

This ratio shows what percentage of the company's distributable earnings is being paid to the ordinary shareholders in the form of dividend. Dividend payout ratio $=$ dividend per share/earning per share.

\subsubsection{Net Profit Margin}

This indicates the Naira amount of the net profit the firm accrued from each Naira of net sales. Net Profit Margin $=$ Net profit $/$ Sales.

\subsubsection{Return on Assets}

This indicates management performance in using the company's total assets to generate return. $\mathrm{ROA}=\mathrm{PBIT} /$ Total assets.

\subsubsection{Return on Equity}

It shows the efficiency of management to maximize the return accrue to Shareholders base on their investment in the business. ROE = PBIT/Equity.

From the foregoing, according to Deltacpe (2014), Ratios are generally not significant of themselves but assume significance when they are compared with: 1) previous ratios of the same firm, 2) some predetermined standards 3) ratios of other enterprises in the same industry, or 4) ratios of the industries within which 
the company operates. Therefore, for this research, the two companies will be compared as identified above.

\section{Data Presentation, Analysis and Discussions}

This section presents the dividend payout ratio and profitability ratio analysis carried out on the financial statements of Mobil Plc and Total Plc from 2015 to 2018.

Table 1 revealed that, in 2015 Mobil Plc has net profit margin of 9.2\% while Total Plc has just 3\%. In the same year that Mobil Plc generate return from the use of assets at $12.7 \%$, Total Plc has $7.7 \%$, this shows that the management team of Mobil Plc performed excellently well in generating return on the total assets invested than Total Plc. Return on equity of Mobil Plc stood at $44.9 \%$ which is $5.9 \%$ greater than that of Total Plc. As already seen that Mobil Plc performed well than Total Plc in generating profit, this made it pay $48.8 \%$ out of its earnings to the shareowners, while Total Plc could only afford to payout just $18.3 \%$ of its earnings. This suggests that, in 2015, the financial performance of Mobil Plc was smooth when compared to Total Plc that operates in the industry. As the shareholders in Total Plc got less than Mobil Plc, this shows that, there are some weaknesses in the Total Plc affecting revenue generation which needs proper attention of the company management, as this could discourage the equity holders to sell their shares to avoid more risks and at the sametime preventing prospective investors from coming in to invest. Panic share sales can trigger share price loss.

Table 2 shows that, despite the fact that Mobil Plc has Net Profit Margin of $12.4 \%$ which is $5.3 \%$ higher than what Total Plc generated, and at the same time Return of Assets which accrued $19.4 \%$ which is $4.6 \%$ greater than what Total Plc generated. The performance of Total Plc was improved in generating return to equity holders by having $86.3 \%$ which is greater than $56 \%$ of Mobil Plc. And as a result of that, Total Plc paid out 39\% of its earnings to shareholders, while Mobil Plc paid just 25.4\%. In a nutshell, there was a lot of improvement in Total Plc in 2016.

In Table 3, despite the ability of Total Plc to generate Net Profit Margin and Return on Assets below what the management team of Mobil Plc generated, it returns on equity stood at $41.7 \%$ which is $0.9 \%$ greater than what Mobil Plc accrued. For that, Total Plc paid out huge amount of $71.9 \%$ as dividend to the shareholders and ploughed back just $28.1 \%$ for other profitable investment. In this case, it has done better than Mobil Plc as the shareholders will have confidence and could also attract prospective investors.

In 2018, the financial performance ratios show that Mobil Plc performed far better than Total Plc (Table 4). In spite of that, Total Plc was able to pay a higher percentage as dividend to shareholders, an amount it competitor cannot afford. This suggests that, the dividend payout ratio of Mobil Plc has insignificant effect on it financial performance. 
Table 1. Comparing Mobil Plc and Total Plc variables 2015.

\begin{tabular}{ccc}
\hline Variables & Mobil Plc & Total Plc \\
\hline Net Profit Margin & $9.20 \%$ & $3.00 \%$ \\
Return on Assets & $12.70 \%$ & $7.70 \%$ \\
Return on Equity & $44.90 \%$ & $39.00 \%$ \\
Dividend payout & $48.80 \%$ & $18.30 \%$ \\
\hline
\end{tabular}

Sources: Audited Financial Statement of Mobil Plc and Total Plc 2015.

Table 2. Comparing Mobil Plc and Total Plc variables 2016.

\begin{tabular}{ccc}
\hline Variables & Mobil Plc & Total Plc \\
\hline Net Profit Margin & $12.40 \%$ & $7.10 \%$ \\
Return on Assets & $19.40 \%$ & $14.80 \%$ \\
Return on Equity & $56.00 \%$ & $86.30 \%$ \\
Dividend payout & $25.40 \%$ & $39.00 \%$ \\
\hline
\end{tabular}

Sources: Audited Financial Statement of Mobil Plc and Total Plc 2016.

Table 3. Comparing Mobil Plc and Total Plc variables 2017.

\begin{tabular}{ccc}
\hline Variables & Mobil Plc & Total Plc \\
\hline Net Profit Margin & $10.00 \%$ & $4.20 \%$ \\
Return on Assets & $14.90 \%$ & $10.90 \%$ \\
Return on Equity & $40.80 \%$ & $41.70 \%$ \\
Dividend payout & $38.00 \%$ & $71.90 \%$ \\
\hline
\end{tabular}

Sources: Audited Financial Statement of Mobil Plc and Total Plc 2017.

Table 4. Comparing Mobil Plc and Total Plc variables 2018.

\begin{tabular}{ccc}
\hline Variables & Mobil Plc & Total Plc \\
\hline Net Profit Margin & $8.00 \%$ & $3.10 \%$ \\
Return on Assets & $19.30 \%$ & $9.10 \%$ \\
Return on Equity & $40.50 \%$ & $39.30 \%$ \\
Dividend payout & $30.80 \%$ & $72.00 \%$ \\
\hline
\end{tabular}

Sources: Audited Financial Statement of Mobil Plc and Total Plc 2018.

\section{Summary of Findings, Conclusion and Recommendations}

Dividend payout ratio had a negative and insignificant effect onfinancial performance of Mobil Plc and Total Plc in 2017 and 2018, while the results showed significant effect in 2015 and 2016 for Total Plc, and significant effect for Mobil $\mathrm{Plc}$ in 2015 but insignificant effect in 2016. When a firm changes its dividends payout ratio, investors assume that it is in response to an expected change in the 
firm profitability which will last long. An increase in payout ratio signals to shareholder a long term increase in firm's expected earnings.

\section{Conclusion}

The payment of dividend and the payout ratio conveys to shareholders that the company is profitable and financially strong. Dividend policy can affect the value of the firm and in turn, the wealth of shareholders. Dividend payout ratio can predict future earnings and hence be used to determine financial performance. From the study findings and discussion, the study concludes that in 2015, dividend payout ratio of Mobil Plc and Total Plc fully depend on the financial performance ratios suggesting that it has significant effect. While in 2016, as the profitability ratios of Mobil Plc became insignificant, that of Total Plc remained significant. But in 2017 and 2018, the two companies recorded insignificant effects.

The study recommends that managers should: design a dividend policy that will enhance financial performance and therefore shareholders value; reduce their total debts to increase financial performance of firms and shareholder value; and devote adequate time in designing a dividend policy that will enhance financial performance and therefore shareholder value.

The study also recommends that: the selected oil and gas companies in Nigeria should pay more attention to leverage and profitability ratio which influence dividend payout positively; and that investors should use this information to make better investment decisions regarding which industries to invest in order to reap better benefits in terms of dividends.

\section{Conflicts of Interest}

The authors declare no conflicts of interest regarding the publication of this paper.

\section{References}

Adefila, J. J., Oladipo, J. A., \& Adeoti, J. O. (2013). The Effect of Dividend Policy on the Market Price of Shares in Nigeria: Case Study of Fifteen Quoted Companies. http://www.scribd.com/doc/132398617/14-the-Effect-ofDividend-Policy-1

Adelegan, O. J. (2003). An Empirical Analysis of the Relationship between Dividend Changes and Cashflow in Nigeria. African Development Review, 15, 35-49. https://doi.org/10.1111/1467-8268.00061

Aharony, J., \& Swary, I. (1980). Quarterly Dividend Earnings Announcements and Stockholders Returns: An Empirical Analysis. Journal of Finance, 35, 1-12. https://doi.org/10.1111/j.1540-6261.1980.tb03466.x

Amadasu, D. (2011). Dividend Is Relevant: A Restatement. African Research Review, 5, 60-72. https://doi.org/10.4314/afrrev.v5i4.69259

Ambarish, R., John, K., \& Williams, J. (1987). Efficient Signalling with Dividends and Investments. Journal of Finance, 42, 321-343. https://doi.org/10.1111/j.1540-6261.1987.tb02570.x 
Amihud, Y., \& Murgia, M. (1997). Dividend, Taxes, and Signaling: Evidence from Germany. The Journal of Finance, 52, 397-408. https://doi.org/10.1111/j.1540-6261.1997.tb03822.x

Asquith, P., \& Mullins, D. (1983). The Impact of Initiating Dividend Payments on Shareholder Wealth. Journal of Business, 56, 77-96. https://doi.org/10.1086/296187

Baker, H. K., Powell, G. E., \& Veit, E. T. (2002). Revisiting Managerial Perspectives on Dividend Policy. Journal of Economics and Finance, 26, 267-283. https://doi.org/10.1007/BF02759711

Baskin, J. (1989). Dividend Policy and the Volatility of Common Stock. Journal of Portfolio Management, 15, 19-25. https://doi.org/10.3905/jpm.1989.409203

Benartzi, J., Michaely, R., \& Thaler, R. (1997). Do Changes in Dividends Signal the Future or the Past? Journal of Finance, 52, 1007-1034. https://doi.org/10.1111/j.1540-6261.1997.tb02723.x

Bierman, H. (2001). Increasing Shareholder Value: Distribution Policy, a Corporate Challenge. Boston, MA: Kluwer Academic Publishers. https://doi.org/10.1007/978-1-4615-1505-0

Black, F., \& Scholes, M. (1974). The Effects of Dividend Yields and Dividend Policy on Common Stock Prices and Return. Journal of Financial Economics, 1, 1-22. https://doi.org/10.1016/0304-405X(74)90006-3

Brigham, E. F., \& Gapenski, L. C. (1994). Financial Management: Theory and Practice. Hinsdale, IL: Dryden Press.

Brigham, E. F., \& Houston, J. F. (2004). Fundamentals of Financial Management (10th ed.). Mason, $\mathrm{OH}$ : Thomson/South-Western.

Brittain, J. A. (1964). The Tax Structure and Corporate Dividend Policy. American Economics Review, 54, 272-282.

Chariton, A., \& Vafeas, N. (1998). The Association between Operating Cash Flows and Dividend Changes: An Empirical Investigation. Journal of Business Finance and Accounting, 25, 225. https://doi.org/10.1111/1468-5957.00185

De Angelo, H., De Angelo, L., \& Skinner, D. J. (1996). Reversal of Fortune: Dividend Signaling and the Disappearance of Sustained Earnings Growth. Journal of Financial Economics, 40, 341-371. https://doi.org/10.1016/0304-405X(95)00850-E

Deltacpe, L. L. C. (2014). Analysis and Uses of Financial Statements.

Dhillon, U. S., \& Johnson, H. (1994). Corporate Dividend Behavior with Special Emphasis on Growth and Controlled Companies (pp. 25-30). Unpublished Doctoral Dissertation, Ahmedabad: Indian Institute of Management.

Foong, S. S., Zakaria, N. B., \& Tan, H. B. (2007). Firm Performance and Dividend Related Factors: The Case of Malaysia. Labuan Bulletin of International Business \& Finance, 5, 97-111.

Gordon, M. J. (1963). Optimal Investment and Financing Policy. The Journal of Finance, 18, 264-272. https://doi.org/10.1111/j.1540-6261.1963.tb00722.x

Gwaya, D. K., \& Mwasa, D. I. (2016). Effect of Dividend Payout on Financial Performance among Public Limited Companies in Kenya. International Journal of Social Sciences and Information Technology, 2, 642-651.

Hashemijoo, M., Ardekani, D., \& Younesi, R. (2012). The Impact of Dividend Policy on Share Price Volatility in the Malaysian Stock Market. Journal of Business Studies Quarterly, 4, 111-129.

Jo, H., \& Pan, C. (2009). Why Are Firms with Entrenched Managers More Likely to Pay 
Dividends? Review of Accounting and Finance, 8, 87-116. https://doi.org/10.1108/14757700910934256

Lang, L. H. P., \& Litzenberger, R. H. (1989). Dividends Announcements Cash Flow Signalling versus Cash Flow Hypothesis? Journal of Financial Economics, 24, 81. https://doi.org/10.1016/0304-405X(89)90077-9

Lintner, J. (1956). Distributions of Incomes of Corporations among Dividends, Retained Earnings and Taxes. American Economic Review, 46, 97-113.

Lintner, J. (1956). Optimal Dividends and Corporate Growth under Certainty. The Quarterly Journal of Economics, 78, 49-95. https://doi.org/10.2307/1880545

Miller, M., \& Rock, K. (1985). Dividend Policy under Asymmetric Information. Journal of Finance, 40, 1031-1051. https://doi.org/10.1111/j.1540-6261.1985.tb02362.x

Modigliani, F., \& Miller, M. (1961). Dividend Policy, Growth and Valuation of Shares. The Journal of Business, 34, 411-433. https://doi.org/10.1086/294442

Musyoka, C. S. (2015). The Effect of Dividend Policy on the Financial Performance of Firms Listed at the Nairobi Securities Exchange. Published Master Thesis, Nairobi: University of Nairobi.

Nazir, M. S., Musarat, M., Waseem, N., \& Ahmed, A. F. (2010). Determinants of Stock Price Volatility in Karachi Stock Exchange: The Mediating Role of Corporate Dividend Policy. International Research Journal of Finance and Economics, 55, 100-107.

Nissim, D., \& Ziv, A. (2001). Dividend Changes and Future Profitability. Journal of Finance, 56, 2019-2065. https://doi.org/10.1111/0022-1082.00400

Odularu, G. O. (2008). Crude Oil and the Nigerian Economic Performance. Oil and Gas Business. Geneva: World Trade Organization Centre, Willian Rappard. http://www.ogbus.ru/eng

Pandey, I. M. (2003). Corporate Dividend Policy and Behaviour the Malaysian Evidence. Asian Academy of Management Journal, 8, 17-32.

Pandey, I. M. (2010). Financial Management (10th ed.). New Delhi: Vikas Publishing House PVT Ltd.

Pettit, R. R. (1972). Dividend Announcement, Security Performance and Capital Market Efficiency. Journal of Finance, 27, 993-1007. https://doi.org/10.1111/j.1540-6261.1972.tb03018.x

Rahel, T. Z., \& Serkalem, T. B. (2010). The Impact of Board Composition on Accounting Proftability of the Firm.

Rahim, R., Yaacob, M. H., Alias, N., \& Mat Nor, F. (2010). Investment, Board Governance and Firm Value: A Panel Data Analysis. International Review of Business Research Papers, 6, 293-302.

Rashid, A., \& Rahman, A. (2008). Dividend Policy and Stock Volatility: Evidence from Bangladesh.

Uwuigbe, U., Jafaru, J., \& Ajayi, A. (2012). Dividend Policy and Firm Performance: A Study of Listed Firms in Nigeria. Accounting and Management Information System, 2, 442-454.

Van Horne, J. C. (1971). Fundamentals of Financial Management. Upper Saddle River, NJ: Prentice Hall.

Wansley, J. (2003). Dividend Policy Theory and Practice. In G. M. Frankfurter, \& B. G. Wood (Eds.), Dividend Policy Theory and Practice (Chapter 13, pp. 173-185). Cambridge, MA: Academic Press.

Waswa, C. W., Fredrick, W. S., Ndede, F. W. S., \& Jagongo, A. O. (2014). Dividend 
Payout by Agricultural Firms in Kenya: An Empirical Analysis of Firms Listed on the Nairobi Security Exchange. International Journal of Business and Social Science, 5, 63-74.

Watts, R. (1973). The Informational Content of Dividends. Journal of Business, 46, 191-211. https://doi.org/10.1086/295525

Welch, I. (2009). Corporate Finance: An Introduction to Corporate Finance. Upper Saddle River, NJ: Prentice Hall.

William, L. M., \& Scott, B. S. (2009). Introduction to Corporate Finance ( $2^{\text {nd }}$ ed., Abridged Edition). Ohio: South-Western, Cengage Learning Academic Resources Center, 196. http://4wkt.net/f/xhimlhjrvac6rk7.pdf

Zakaria, Z., Muhammad, T., \& Zulkifli, A. H. (2012). The Impact of Dividend Policy on the Share Price Volatility: Malaysian Construction and Material Companies. International Journal Economics and Management Sciences, 2, 1-8.

Zanjidar, M., \& Seifi, M. (2012). Review of Relationship between Dividend Policy and Performance: Evidence of Iran's Capital Market. African Journal of Business Management, 6, 10507-10513. https://doi.org/10.5897/AJBM11.2860 